\title{
The Influence of Audit Team and Inner Audit Features on Inner Audit Quality and Audit Fees
}

\author{
Omar Turki Hazzaa, Dewi Fariha Abdullah
}

DOI: $10.37648 /$ ijrssh.v10i04.007

Received:30 th August, 2020; Accepted:30th September, 2020; Published:03rd October, 2020

\section{CHAPTER I: INTRODUCTION}

\subsection{Background of Study}

The internal audit function is one of the key components in measuring the good governance that developed toward the maturity with the passage of time(Nitonde, 2016). The internal audit was considered as 'watchman' of the organization in past but its effectiveness and requirement have seen significant modification in the recent years. The reason for such modifications was due to the increase in the organizational structure and working complexities and the conversion of theworld into a global village. The modified function of the internal audit now works as a consultation that includes risk management. Control assurance, and compliance work (Bubilek, 2017; Stewart \& Subramaniam, 2009). Resultantly, such improvements and expansions compelled the research community as well as the business to evaluate and improve the role of internal audit in the business. In specific, the researchers are focusing that how the internal audit can contribute to the external audit. They emphasize on the issues that could affects the role of the internal audit positively.

Despite the different and distinguishable functions of the internal and external audit, they share some basic characteristic and both lead the similar nature of the outputs. Such similar outcomes are the transparent financial system that reduces and minimize the economic risk for the organization. The professional audit standards recognize the positive effects of the internal audit to the external audit (Board, 1991; No, 2007). Such positivity can be provided in a two manner, i.e., the internal audit can support the external audit functionality by providing the assistive services to the external team and secondly, the internal audit can perform their activities independently from the external audit but provide the basis on which the external audit can trust. The second type of support can be provided by the performing the internal audit and the financial reviews throughout the financial year (Maletta \& Kida, 1993). Nevertheless, the important aspect in the success of the supportive role of the internal audit for the external audit depends on the excellence of the internal audit (Desai, Desai, Libby, \& Srivastava, 2017). In this instance, the excellence of the internal audit role has become the focal factor for external auditor's consideration before the decision to coordinate or trust on the IAoutcomes could be undertaken. Given the current emphasis on the excellence of the IA role, it is time that research directed to that issueis to be undertaken.

The past experimental research related to the internal audit is mainly emphasizing on background and consequences of the IA role in the context of the financial statement audit. In the context of the backgrounds or the effective factors of the external audit outcomes based on the internal audit. The past studies mainly emphasized on the investigation of the features that are described in the professional auditing standards (Desai et al., 2017). The main focus of these studies was on the ranking of this feature to prioritize them according to their importance. Such importance is measured in the 


\section{(IJRSSH) 2020, Vol. No. 10, Issue No. IV, Oct-Dec}

context of the external audit by evaluating the strength of the internal audit roles. These factors and their strength ultimately influence the nature and need of the importance and its inclusion as a base for the external audit. Additionally, instead of the direct measurement of the IA factors, these studies focus on the relative importance and trust of these functions by the external auditors. In this way, the auditors can use the IA as aproxy for the IA quality in suggesting the higher degree of reliance on IA function reflects that the IA function has sufficient level of quality.

The experimental studies in the recent past using different tools proposed to consider the other aspects of the IA roles. The other aspects can be the objectivity, productivity, efficiency, and effectiveness of the employees during the working hours (Abbott, Daugherty, Parker, \& Peters, 2016; Abdul Khalik, Snowball, \& Wragge, 1983; Brown, 1983; Desai et al., 2017; Edge \& Farley, 1991; Gramling, Maletta, Schneider, \& Church, 2004; Haron, Chambers, Ramsi, \& Ismail, 2004; Krishnamoorthy, 2002; Margheim, 1986; Said Suwaidan \& Qasim, 2010; Schneider, 1984). In this connections, theKrishnamoorthy (2002) usedinference theory which is a relatively advanced multi-phased analytical technique. He concluded that ranking of the key features possesses less effectiveness due to lacking the dominance factors at the individual level in general. These studies suggest that the external auditors want to trust on the IA's output if sufficient level of quality is clearly demonstrated in the objectivity, competency and work performance of the internal audit role.

The experimental outcomes till now related to the key features that influencing the dependence of the external audit on the IA's outcomes is diverse. This key features an also highlighted in the professional standards for evaluating the excellence of the internal audit roles. Additionally, these researchers are more concentrated towards the increase in the trust level of the external auditors on the outcome of the IA work. But, in the comparison to these past researches, the new studies are evaluating the quality of internal audits using the direct evaluation of the external audits' point of view about the excellence of the internal audit roles.

\section{e-ISSN: 2249-4642, p-ISSN: 2454-4671}

In the association to the output of the IA work in the finance section's audit, the details from the perspective of the governmental organization and researchers highlighted that external auditors frequently trust the internal auditor's report during the financial audit for cost minimization and improving the effectiveness (Elliot, Korpi, \& Melvin, 1978; Peacock \& Pelfrey, 1989; Wallace, 1984; Ward \& Robertson, 1980) supported a negative relationship, whereby the result suggests that audit feedecrease as dependence on the by external audit workers on internal auditors rises. Likewise, (Carey, Simnett, \& Tanewski, 2000; Stein, Simunic, \& Keefe, 1994)investigated the effects of the internal audit roles to external audit on audit fees. However, both studies found no supporting result to show the adverse relationships in the external audit workers dependence on the internal auditors their associated fees.

The research strand is extended by (Felix $\mathrm{Jr} \&$ Gramling, 2001). Firstly, it examines the internal audit function attributes judgment of external auditors and its effects on the willingness of auditors. This willingness relies on the internal audit work. Secondly, it focuses on the internal audit work concept and its influence on the external auditors'. For instance, the work accomplished in relation with the examinations of the internal control organization reliance on the internal audit. The empirical findings suggested that external auditor's dependency is affected by their opinions of the internal audit function quality. Moreover, the results also indicate the condition on the certain level of innate risk, the accessibility of internal auditors and the level of regulation between internal auditors and external auditors. Additionally, the internal audit function contribution to external audit work specifically in the process of financial statement process that minimizes the external audit fee. However, the research study supported by (Felix Jr \& Gramling, 2001) exclude the direct relationship of IA quality on audit fees. Instead, IA quality is treated as one of the important determinants for external auditors to depend upon IA work. In contrast, to the discussed past studies, the literature emphasized the positive association between IA function existence and audit fees. The research identifies that the auditing organization mechanisms may use theinternal and external audit as an integrated monitoring system. The basic aim of these 
(IJRSSH) 2020, Vol. No. 10, Issue No. IV, Oct-Dec

entities to maximize the quality of audit operations within the organization.

More recently, (Bubilek, 2017; Prawitt, Sharp, \& Wood, 2011)investigated the relationship between the two groups through the assistive work and trust of the external audit team using the quality of the work. They also evaluated the fee with and without the assistive work of the internal audit. This research also analyzed the association between two groups with respect to the time that how much time the internal team is spending while providing a direct assistive help to the external team. They also compared the time spent by the internal team and the trustworthy work acceptable to the external team.

In the recent past,(Abbott et al., 2016), used two factors based technique to evaluate the quality of the IA function and its capability to identify the financial mistakes. This ability is known as the competence of the audit team. The second factor, known as Independence, is the inclination to testify the mistake to the internal or external team.

Also (Carcello, Eulerich, Masli, \& Wood, 2017)examined whether internal auditing provides value to organizations by reducing operational, financial, compliance, and overall risk. They employed a unique research design wherein they compare the changes in risks between audited business units and matched nonaudited units within the same company. This design lets to isolate the importance of an internal audit while holding constant changes in risk due to the organization and time period.

Furthermore, (Raiborn, Butler, Martin, \& Pizzini, 2017) distinguished the duties of the internal and external audit workers, highlighted the advantages of the internal team, emphasises on the function performed by the internal team to focus on the organizational risk management, showshow the assurance and consulting tasks of the internal auditors increases the institutional value, and reviews the cost-effective preferencesto effectively implement the internal audit function.

In the nutshell, the past researcher intensively examined the association among the features that influence the level of the dependency of the external
e-ISSN: 2249-4642, p-ISSN: 2454-4671

team on the work of the internal team and how the internal team contributes to the financial audit and itsnexus with the audit fee. But, the past researcher did not inspect the impact of the external team on the quality of the internal team and its effects on the fee. Such investigation is necessary as the external and internal audit teams or the main pillar to main the organizational supremacy as proven by the past studies. The effective an efficient audit team, internal as well as external, help the top management to excellently monitor and control the financial matter inside the organization.

\subsection{Problem Statement}

In the past years, anincreasing number of audit firms in the market increases the rivalry among these firms. But the complexity of the organization added more issue to the audit that increases the role of internal auditor as well. Thus making both teamsan indispensableelement of the organization and the financial soundness and effectively is strongly associated with the effectiveness of these teams (Felix Jr \& Gramling, 2001).The level of competition among the firms, however, compelled them to the minimize the incurring cost while improving the efficiency.

The analysis of the past research specified that a number of the experimental researches are done in the context of developed countries despite having complex and advanced monitor systems. The past studies focused on the influencing factors of the input from the internal team and its effectiveness in the financial statement. However, they produced differing results in the association of the factors as compared to the parameters identified by the professional standards for evaluating the excellence of the internal audit.

Additionally, the past studies have limited resources to show the crossed effects of the external auditors' trust on the internal team's work. Thus, this research will concentrate on the identification of the causes of the internal audit quality and investigation of the possibility of the influences that can be resulted from the perceptions of the external auditors. This external auditor perception is associated with the contribution on the IA in term of the financial audit, internal audit quality, and the succeeding results of such evaluation of the external audit fee.

\section{INTERNATIONAL JOURNAL OF RESEARCH IN SOCIAL SCIENCES AND HUMANITIES}


(IJRSSH) 2020, Vol. No. 10, Issue No. IV, Oct-Dec

\subsection{Research Questions}

In order to find asolution for the issue raised, this research will try to find the answer to these research questions.

i. Is there any association in the internal audit factors and the quality of the IA roles?

ii. Is there any association in the audit committee characteristics and the internal audit's roles?

iii. Is there any adverse association in the degree of the IA contribution to the financial audit, IA quality, and incurring fees?

\subsection{Research Objectives}

This research is mainly focusing on investigating the association between the IA and the committee characteristics with respect to the quality of internal audit functions. In addition, this research will further examine the association in the internal audit quality andinternal audit contributions. The objectives to be achieved in this research are:

i. To investigate the relationship in the internal audit attributes and the quality of theinternal audit.

ii. To investigate the association in the audit committee attributes and the IA quality.

iii. To examine the effects of internal audit contribution to financial audits with respect to fees.

iv. To examine the effects of internal audit quality with respect to fees.

\subsection{Aim of the study}

This research aims to investigate the causes of the IA and audit committee's characteristics with respect to the effectiveness of the internal audit quality. Furthermore, this research will also focus on the association among the quality of IA, internal audit contribution to the financial audit and fees.
e-ISSN: 2249-4642, p-ISSN: 2454-4671

\subsection{Contribution of study}

This research will specifically contribute to the gap in both the audit fees and corporate governance literature, and the practice of auditing. In terms of the contribution to the development of the literature, this research will cover the gap in the knowledge base by investigating the effects of the two main features of the organizational supremacy; i.e., the IA and audit committee attributes and their association with the IA quality.

\section{CHAPTER II: LITRETURE REVIEW}

\subsection{Overview}

This chapter highlights the three sections. The first section explains an overview of the theoretical linkages among three integral part of organizational monitoring mechanisms, such as inner audit function, audit committees, and external audit. Specifically, agency theory concept has been started in conceptualization the roles and relationship among mechanisms. The second section provides the extensive literature on external audit team perception about the affectivity of the on internal auditors. The auditor's decision depends on the output of the internal auditorsand its quality. The last section examining the determinants of audit fees.

\subsection{Agency Theory}

The concept of "separation of ownership and control" firstly introduced by (Berle \& Means, 1991) within the organization. The idea is further extended by (Fama, 1980). It is debated that there is apossibility for deviation in control and decision making may exist, when management and ownership are separated. In this regards, the role of management is to perform duties as a replacement of the owner. The owner, then, seeks the devious behavior of these agents because the decision power and controlling authority are now these agents. In this perspective, Management acts as an agent for the owners of theorganization. These owners are also called "Principle". In it, the owners or principle are shown to the resourceful attitude of the agents or management. This process is continuing till the decision making and control are authorized to the management. In particular, the agency association can be discussed as, "a contract 
(IJRSSH) 2020, Vol. No. 10, Issue No. IV, Oct-Dec

under which one or more persons, the principal(s), engage another person (the agent) to perform some service on their behalf which involves delegating some decision making authority to the agent (Jensen \& Meckling, 1979).

(Ferdinand)) emphasized the two basic issues associated with the management process. This process is the outcome of the dissolution of ownership and control. The first problem is that the goals of management and owners may not be affiliated. In general, the managers in individual capacity are considered as the efficacy maximize working for self-benefits. Whereas, the top management is not interested in only the maximization of the efficacy but they are interested in the overall return on the investments. The latter issue raises the complication for the owner due to lack of business and financial knowledge. Therefore, the owner cannot monitor the activities of the individual manager. Resultantly, both the owner and the individual manager
e-ISSN: 2249-4642, p-ISSN: 2454-4671

have inducements in the different system to minimize the managerial expenses related to the information irregularities (Fama, 1980; Jensen \& Meckling, 1979).

The high-quality control devices and the information systems providerelatively cost effective solutions to the associated customers. One system is to choose the managers with the opposite moral characteristics. It will help the organization by ensuring that both are monitored and will result in minimized ethical danger to the organization (Alchian \& Demsetz, 1972; Jensen \& Meckling, 1976). Adversely, theoretically, it is admissible to apply a number of restrictive systems to support and gain the interest of the individual manager, the owner, and the monitoring managers. In this research, the three key factors are examined, i.e. the internal audit functions, the committee, and the external audit. Figure 2.1 shows their association in the broader perspective. 


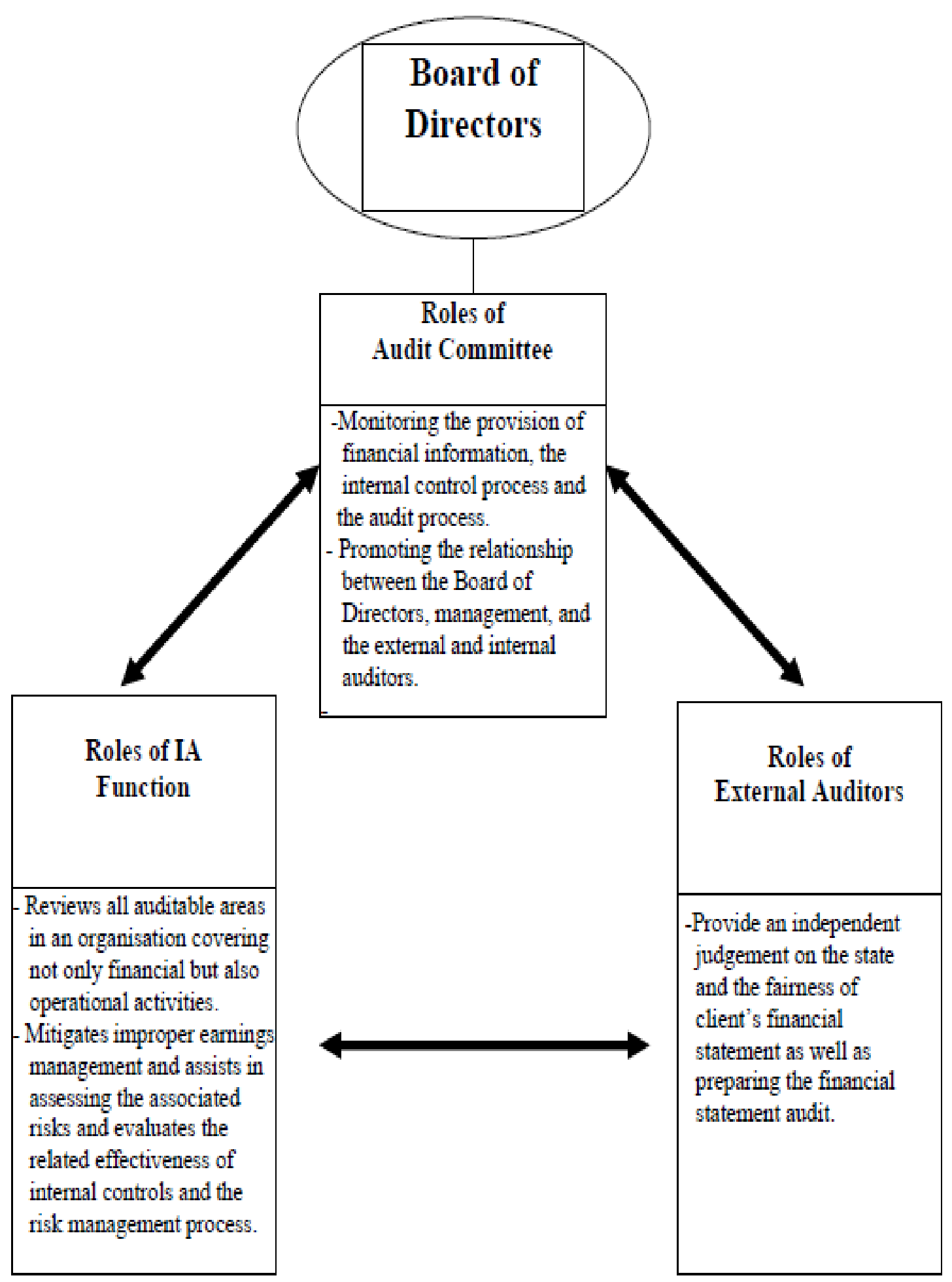

Figure 2.1: The association among theaudit committees, internal audit function, and external auditors. 
2.3 The Association Among the Audit Team, Functions, and external Auditors

The association of the organizational supremacy that deals with the internal audit have been extensively studied in the recent past. The particular attention is paid to the roles played by the internal audit in maintaining the organizational supremacy. There are four main pillars that associate an internal audit function, audit committees, and external auditors. These pillars are aboard of directors, IA function, management and theexternal auditor.

The Board of Directors of an organization has the duty to ensure that the organization is running well and achieving the main goals set by all stakeholders thus responsible for ensuring the organizational supremacy. The board is working a middle man between the top level management and the organization owners. It is the duty of the board to guard the interest of every stakeholder. The inappropriate activities of the individual managers may have conflicts with the owners and may not perform the duties in the interest of the owner (Fama, 1980; Jensen \& Meckling, 1979). Thus, to reduce the risk, the board is considered a monitoring body that specifically watching the top level management. The board is known as the final approval unit. In addition, the board is also responsible for keeping an eye on the organizational financial activities to ensure the accuracy in financial transactions. If the organization is listed as a public company, then it legally bound for an annual financial audit.

The board of directors normally produce its own understandings associated with the financial activities to the auditors. The auditors comprise the audit committee. It is sub-unit comprises of mid-level directors or directors that are not dependent and who are responsible for looking at the issues associated with the financial activities, reporting and control (Dechow, Sloan, \& Sweeney, 1996; Spira, 1999; Turley \& Zaman, 2004).

The audit committee is important by its role as they are performing as abridge that improves the trust level between the executives, internal audit team, and external audit team (Bradbury, 1990; DeZoort, 1997). Furthermore, (Menon \& Williams, 1994) suggested that the board is achieving two-fold benefits from the audit committee, i.e., the independence and efficiency. Independence from the management can be gained by the getting the reports from the internal and external team. The board can improve its efficiency by getting the backing from a powerful committee that is monitoring the financial matters and evaluating the performances (Zahra \& Pearce, 1989).

\subsection{Brief Review of the Empirical Studies}

The extensive review of the past studies indicates that four major strands exist associated to IA quality. Most of the literature emphasized to use proxy measure for IA quality i.e. internal audit contribution to financial statement audits. The first strand examines the internal audit function attributes judgment of external auditors and its effects on the willingness of auditors. This willingnessrelies on the internal audit work. The second strand focuses on the internal audit work concept and its influence on the external auditors'. For instance, the work accomplished in relation with the examinations of the internal control organization reliance on the internal audit. The third strand scrutinizes the relation between audit committee attributes and the extent of internal audit contribution to financial statement audits. Lastly, the fourth strand investigates whether the IA contribution to financial statement audits minimizes the fees that are paid to external auditors. The Research and Development (R\&D) of these strands will be further elaborated leading to the recognition of the gaps in the literature.

The recent researches study purpose to fill the gap in thebody of literature. Firstly, the study aimed to examine the determinants under "Attributes of the IA Function" and "Other Governance and Organisational Process or audit committee attributes". Secondly to investigate the association between the two key features of internal audit (IA). These aspects are, such as external auditors' assessments of internal audit contribution to financial statement audits and internal audit quality relating to external audit fees. The main contribution of thecurrent study is to indicate the influence of committee audit attributes. These audit committee attributes are, namely, (1) the frequency of audit committee's meeting; private meetings between chief audit executive and audit

\section{INTERNATIONAL JOURNAL OF RESEARCH IN SOCIAL SCIENCES AND HUMANITIES}


(IJRSSH) 2020, Vol. No. 10, Issue No. IV, Oct-Dec

committee; (2) the independence of audit committee; (3) the dissolution of audit committee and risk management function. Moreover, the internal audit function attributes are, such as (1) the internal audit staff professional qualification; (2) the IA function Age existence in the organization; (3) the IA staff's prior experience. The internal audit staff knowledge and skills experience in the field of auditing, computers and information technology.

\subsection{Summary}

The internal auditors, audit committee and external auditors are observed to be the component of a greater corporate governance system using an agency theory context. Further, the practical and profitable framework of their roles has symbolic significance for the organization. The extensive literature has shown that the most of the studies pay attention to determine the antecedents. These antecedents impact on the IA contribution towards financial statement audit, and this contribution influences on audit fees.

Therefore, the purpose of this research study is to fill the gap in the body of knowledge to examine that the assessments concerning to IA quality and external auditors are influenced through two key corporate governance mechanisms. These two mechanisms are, such as audit committee features and IA features. Moreover, this research study will also examine the impact of internal audit quality on the fees paid to external auditors. Specifically, an extensive studies review on audit fees shows that the association between internal audit quality and audit fees remains investigated. The empirical findings indicate the relationship between the IA contribution to financial statement audits and audit fees are mutual and questionable. Thus, the future study on these topics is warranted.

\section{CHAPTER III: RESEARCH METHODOLOGY}

\subsection{Overview}

This study uses survey and questionnaire as themain tool in the methodology. The questionnaire will be designed for data collection necessary for the research. The tools that will use in particular is aquestionnaire based survey that will collect data from

\section{e-ISSN: 2249-4642, p-ISSN: 2454-4671}

the archival sources i.e. the annual report that have the companies' data.

\subsection{Methodology}

When deciding what kind of research method one is going to use, there are two main strategies to choose from: quantitative and qualitative. (Cooper, Schindler, \& Sun, 2003), the quantitative and qualitative research methods contain many differences, but short one could say that quantitative research focuses quantification in the data gathering and its analysis while the qualitative research usually highlights words. (Cooper et al., 2003).It is crucial to consider when doing a research that critical thinking is a key to success. Quantitative research methods are rewarding when one wants to analyses numbers but there are a bunch of critical points to keep in mind such as the reliance and procedures hinder the connection between research and everyday life. There is no guarantee that the respondents have enough knowledge to answer a question the way the researcher wishes for(Cooper et al., 2003).

\subsubsection{Qualitative and Quantitative procedure}

Qualitative procedure deals with knowledge and investigation of human's social exists (Guba \& Lincoln, 1994). The focus will be on the social and a human, and on exploring society as well as behavior, both on the micro and macro-level for the social universe. The ability of the phenomenon is done by focusing not on the amount. It will be regarding standard people's knowledge andillustration of their own reality, not the researcher's defined perspectives and recognitionof others' truth. Adaptability around that examination procedure will be significant and the effects need aid dependent upon little samples. On the other hand, the quantitative standard is generally additional exploratory and utilizes exact examination that revealsthe truthabout thesubject being examined. It is basically dependent upon "the feeling for determinism, intending that all occasions would completely resolve with one alternative in a greater amount causes" (Johnson \& Christensen, 2008). The quantitative technique may be basically a deductiveprocedure(Zhao, 2014). This quantitative procedure is required for understanding, comparing, evaluating, predicting, motivating, and great management policies. Therefore, a scientist looks into Qualitative technique as a chosen consideration. The 
(IJRSSH) 2020, Vol. No. 10, Issue No. IV, Oct-Dec

quantitative standard reflects on how they concluded perfect conditions in the reality. (Golafshani, 2003) represented quantitatively as having "charts with graphs define the outcomes of the research".

For this study mix,qualitativeand quantitative procedure will nominate. The reasons for choosing a researcher qualitative and quantitative procedure as the main study tool was mainly due to it being a practical and effective way of producing amodel for auditing
e-ISSN: 2249-4642, p-ISSN: 2454-4671

sector (De Vaus \& de Vaus, 2001).

\subsection{Summary}

This chapter producesbriefly the methods that will usein this research. It gives some information about thequalitative and quantitative procedure.Specifically, it gives describes the design used to collect the data, how the sampling was done, instruments applied as well as data analysis.

\section{REFERENCES}

Abbott, Lawrence J, Daugherty, Brian, Parker, Susan, \& Peters, Gary F. (2016). Internal audit quality and financial reporting quality: The joint importance of independence and competence. Journal of Accounting Research, 54(1), 3-40.

Abdul Khalik, AR, Snowball, DA, \& Wragge, JH. (1983). The effect of certain internal audit variables on planning and external audit program. The Accounting Review, 58(2), 215-217.

Alchian, Armen A, \& Demsetz, Harold. (1972). Production, information costs, and economic organization. The American economic review, 62(5), 777-795.

Berle, Adolf Augustus, \& Means, Gardiner Gardiner Coit. (1991). The modern corporation and private property: Transaction publishers.

Board, American Institute of Certified Public Accountants. Auditing Standards. (1991). The Auditor's Consideration of the Internal Audit Function in an Audit of Financial Statements: American Institute of Certified Public Accountants.

Bradbury, Michael E. (1990). The incentives for voluntary audit committee formation. Journal of Accounting and public policy, 9(1), 19-36.

Brown, Paul R. (1983). Independent auditor judgment in the evaluation of internal audit functions. Journal of Accounting Research, 444-455.

Bubilek, Olga. (2017). Importance of Internal Audit and Internal Control in an organization-Case Study.

Carcello, Joseph V, Eulerich, Marc, Masli, Adi, \& Wood, David A. (2017). Are Internal Audits Associated with Reductions in Operating, Financial Reporting, and Compliance Risk?

Carey, Peter, Simnett, Roger, \& Tanewski, George. (2000). Voluntary demand for internal and external auditing by family businesses. Auditing: A Journal of Practice \& Theory, 19(s-1), 37-51.

Cooper, Donald R, Schindler, Pamela S, \& Sun, Jianmin. (2003). Business research methods.

De Vaus, David A, \& de Vaus, David. (2001). Research design in social research: Sage.

Dechow, Patricia M, Sloan, Richard G, \& Sweeney, Amy P. (1996). Causes and consequences of earnings manipulation: An analysis of firms subject to enforcement actions by the SEC. Contemporary accounting research, 13(1), 1-36.

Desai, Renu, Desai, Vikram, Libby, Theresa, \& Srivastava, Rajendra P. (2017). External auditors' evaluation of the internal audit function: An empirical investigation. International Journal of Accounting Information Systems, $24,1-14$.

DeZoort, F. (1997). An investigation of audit committees' oversight responsibilities. Abacus, 33(2), $208-227$.

Edge, William R, \& Farley, Alan A. (1991). External auditor evaluation of the internal audit function. Accounting \& Finance, 31(1), 69-83.

Elliot, Robert K, Korpi, Alan R, \& Melvin, F Shaken. (1978). Factors affecting audit fees, in cost benefit analysis of auditing. Commission on Auditors' Responsibility.

Fama, Eugene F. (1980). Agency Problems and the Theory of the Firm. Journal of political economy, 88(2), $288-307$. 
Felix Jr, William L, \& Gramling, Audrey A. (2001). The contribution of internal audit as a determinant of external audit fees and factors influencing this contribution. Journal of Accounting Research, 39(3), 513-534.

Ferdinand, AG. Hong Kong Auditing: Economic Theory and Practice, latest edition. City University of Hong Kong Press.

Golafshani, Nahid. (2003). Understanding reliability and validity in qualitative research. The qualitative report, 8(4), 597606.

Gramling, Audrey A, Maletta, Mario J, Schneider, Arnold, \& Church, Bryan K. (2004). The role of the internal audit function in corporate governance: A synthesis of the extant internal auditing literature and directions for future research. Journal of Accounting literature, 23, 194.

Guba, Egon G, \& Lincoln, Yvonna S. (1994). Competing paradigms in qualitative research. Handbook of qualitative research, 2(163-194), 105.

Haron, Hasnah, Chambers, Andrew, Ramsi, Rozaldy, \& Ismail, Ishak. (2004). The reliance of external auditors on internal auditors. Managerial Auditing Journal, 19(9), 1148-1159.

Jensen, Michael C, \& Meckling, William H. (1976). Theory of the firm: Managerial behavior, agency costs and ownership structure. Journal of financial economics, 3(4), 305-360.

Jensen, Michael C, \& Meckling, William H. (1979). Theory of the firm: Managerial behavior, agency costs, and ownership structure Economics social institutions (pp. 163-231): Springer.

Johnson, Burke, \& Christensen, Larry. (2008). Educational research: Quantitative, qualitative, and mixed approaches: Sage.

Krishnamoorthy, Ganesh. (2002). A multistage approach to external auditors' evaluation of the internal audit function. Auditing: A Journal of Practice \& Theory, 21(1), 95-121.

Maletta, MJ, \& Kida, T. (1993). The effects of risks factors on auditors' information processing. The Accounting Review, 6(3), 681-692.

Margheim, Loren L. (1986). Further evidence on external auditors' reliance on internal auditors. Journal of Accounting Research, 194-205.

Menon, Krishnagopal, \& Williams, Joanne Deahl. (1994). The use of audit committees for monitoring. Journal of Accounting and Public Policy, 13(2), 121-139.

Nitonde, Rohidas. (2016). Expediting the Quest for Quality: The Role of IQAC in Academic Audit. Online Submission, $3(3), 40-45$.

No, Auditing Standard. (2007). An audit of internal control over financial reporting that is integrated with an audit of financial statements. AUDITING.

Peacock, Eileen, \& Pelfrey, S. (1989). How internal auditors view the external audit. Internal Auditor, 46(3), $48-54$.

Prawitt, Douglas F, Sharp, Nathan Y, \& Wood, David A. (2011). Reconciling archival and experimental research: Does internal audit contribution affect the external audit fee? Behavioral Research in Accounting, 23(2), $187-206$.

Raiborn, Cecily, Butler, Janet B, Martin, Kasey, \& Pizzini, Mina. (2017). The Internal Audit Function: A Prerequisite for Good Governance. Journal of Corporate Accounting \& Finance, 28(2), 10-21.

Said Suwaidan, Mishiel, \& Qasim, Amer. (2010). External auditors' reliance on internal auditors and its impact on audit fees: An empirical investigation. Managerial Auditing Journal, 25(6), 509-525.

Schneider, Arnold. (1984). Modeling external auditors' evaluations of internal auditing. Journal of Accounting Research, 657-678.

Spira, Laura F. (1999). Ceremonies of governance: perspectives on the role of the audit committee. Journal of Management and Governance, 3(3), 231-260.

Stein, Michael T, Simunic, Dan A, \& Keefe, Terrence BO. (1994). Industry differences in the production of audit services. Auditing, 13, 128.

Stewart, Jenny, \& Subramaniam, Nava. (2009). Internal audit independence and objectivity: a review of current literature and opportunities for future research. Griffith Business School, 1, 3-26.

Turley, Stuart, \& Zaman, Mahbub. (2004). The corporate governance effects of audit committees. Journal of management and governance, 8(3), 305-332.

Wallace, Wanda A. (1984). Internal auditors can cut outside CPA costs. Harvard Business Review, 62(2), 16-\&. 
Ward, D Dewey, \& Robertson, Jack C. (1980). Reliance on internal auditors: Can independent auditors use more extensively the work of their internal counterparts? Journal of Accountancy (pre-1986), 150(000004), 62.

Zahra, Shaker A, \& Pearce, John A. (1989). Boards of directors and corporate financial performance: A review and integrative model. Journal of management, 15(2), 291-334.

Zhao, Jill. (2014). Applying Grounded Theory Methodology with Mixed Methods in Occupant Energy Behaviour Research. Paper presented at the The International Academic Forum (IAFOR). 